\title{
Watershed science: Linking hydrological science with sustainable management of river basins
}

\author{
Chansheng $\mathrm{HE}^{1,2^{*}}$ \& L. Allan JAMES ${ }^{3}$ \\ ${ }^{1}$ Department of Geography, Western Michigan University, Kalamazoo, MI 49008, USA; \\ ${ }^{2}$ Center for Dryland Water Resources Research and Watershed Science, Key Laboratory of West China's Environmental System (Ministry of \\ Education), College of Earth and Environmental Sciences, Lanzhou University, Lanzhou 730000, China; \\ ${ }^{3}$ Department of Geography, University of South Carolina, Columbia, SC 29208, USA
}

Received July 26, 2020; revised January 6, 2021; accepted January 20, 2021; published online April 15, 2021

\begin{abstract}
Over the past decades, a number of water sciences and management programs have been developed to better understand and manage the water cycles at multiple temporal and spatial scales for various purposes, such as ecohydrology, global hydrology, sociohydrology, supply management, demand management, and integrated water resources management (IWRM). At the same time, rapid advancements have also been taking place in tracing, mapping, remote sensing, machine learning, and modelling technologies in hydrological research. Despite those programs and advancements, a water crisis is intensifying globally. The missing link is effective interactions between the hydrological research and water resource management to support implementation of the UN Sustainable Development Goals (SDGs) at multiple spatial scales. Since the watershed is the natural unit for water resources management, watershed science offers the potential to bridge this missing link. This study first reviews the advances in hydrological research and water resources management, and then discusses issues and challenges facing the global water community. Subsequently, it describes the core components of watershed science: (1) hydrological analysis; (2) water-operation policies; (3) governance; (4) management and feedback. The framework takes into account water availability, water uses, and water quality; explicitly focuses on the storage, fluxes, and quality of the hydrological cycle; defines appropriate local water resource thresholds through incorporating the planetary boundary framework; and identifies specific actionable measures for water resources management. It provides a complementary approach to the existing water management programs in addressing the current global water crisis and achieving the UN SDGs.
\end{abstract}

Keywords Water crisis, Hydrology, Watershed science, Integrated water resources management (IWRM)

Citation: He C, James L A. 2021. Watershed science: Linking hydrological science with sustainable management of river basins. Science China Earth Sciences, 64(5): 677-690, https://doi.org/10.1007/s11430-020-9723-4

\section{Introduction}

Over the past decades, different water resource management approaches have been developed to tackle the global water shortage and conflicts, such as supply management, demand management, and integrated water resources management (IWRM) (He et al., 2005, 2014, 2020). Simultaneously, hydrology or hydrological science that studies the occurrence,

* Corresponding author (email: He@wmich.edu) distribution, circulation, and properties of water on Earth (NRC, 1991) has evolved to link the atmosphere, land, and oceans to understand the movement of water at all scales and environments and its interaction with climate and life on Earth (NRC, 2012). A number of subdisciplines have also emerged such as ecohydrology (Hannah et al., 2004), global hydrology (Bierkens, 2015), global change hydrology (Tang, 2020), and sociohydrology (Di Baldassarre et al., 2019) to address the interacting and coupled human and natural factors and resulting effects on the occurrence, distribution, 
property, and movement of water at multiple spatial and temporal scales. Despite the tremendous progress in science, technology, and management of water resources over the past few decades, over 2 billion people have no access to safe drinking water, and more than 4 billion people lack access to safely managed sanitation services, water quality problems such as emerging pollutants, nonpoint source pollution, and the spread or invasive species persist globally, and floods and droughts continue to cause huge amount of economic losses and people's lives, affecting over 3 billion people and resulting roughly 179,000 deaths worldwide during the period of 1995-2015 (Gleick, 2016; WWAP, 2019; He et al., 2020). As a result, the World Economic Forum has declared that we are facing a global water-supply crisis (The World Economic Forum, 2013; He et al., 2020). What causes this conundrum? Some scholars have stated global water crisis is a governance crisis (WWAP, 2006; Castro, 2007; Di Baldassarre et al., 2019) and that the absence of an institutional framework in both conventional and integrated water-resources planning and management approaches led to the failure of achieving sustainable water-resources management (Matondo, 2002). Others report that the missing link is effective interactions between researchers and decision makers at different scales (WWAP, 2006; Hering and Ingold, 2012; Cai et al., 2015; Garrick et al., 2017; Di Baldassarre et al., 2019).

Water and water management play key roles in achieving the United Nations Sustainable Development Goals (UN SDGs), particularly Goal \#6: ensuring universal availability and sustainable management of water and sanitation for all (UN, 2019; He et al., 2020). Over the past decades, numerous water sciences and management fields, such as IWRM, ecohydrology, and sociohydrology, have been developed to address pressing water issues across the world. But few have specified the mechanism of integrating water sciences and management at the watershed scale (Johnson et al., 2001; WWAP, 2006; Hering and Ingold, 2012; Cai et al., 2015; Cheng et al., 2014; Li et al., 2015; Garrick et al., 2017; Zipper et al., 2020). This study briefly reviews the evolution of water sciences and management, analyzes the missing links between water sciences and water management, particularly at the watershed scale, and finally proposes a framework of watershed science (WS) to help achieve the UN SDGs.

\section{Evolution of water resources management}

Water resources management (WRM) aims to develop and implement policies, processes, technologies, leadership, and organizations for understanding, distributing, and improving the movement and characteristics of water resources to meet the multiple needs of human societies and ecosystems in a socially responsible, economically viable, and environmentally sustainable way (He et al., 2005, 2020). Since the 20th century, WRM has gradually evolved from supply management, to demand management, to Integrated Water resources Management (IWRM) worldwide (WWAP, 2006, 2019).

For centuries, supply management, i.e., relying on water works such as dams, reservoirs, levees, canals, and transfer projects has been the primary approach to meet the increasing demands for water in a region $(\mathrm{He}, 2012$; He et al., 2005, 2020). Examples of large water works include the Hoover Dam in the United States, the Aswan Dam in Egypt, the Itaipu Dam in Brazil, and the Three Gorges Dam in China (He et al., 2005, 2010, 2020). While having successfully supported flood control, hydropower generation, water supply, food production, urbanization, and economic prosperity worldwide, supply management, especially large water works have also produced multiple environmental and social economic problems, such as loss of riparian habitat, change of river hydrology, damage to aquatic species, relocation of people, and spread of water born diseases (He et al., 2005, 2010; Gleick et al., 2012). Relying on dams or other supplyside increases alone cannot solve global water resource problems (Gleick et al., 2012; Gleick, 2016; He et al., 2005, 2010, 2020).

Freshwater is often a scarce resource where no increase of freshwater supply would be large enough to meet the rapidly increasing multiple demands for water (Gleick et al., 2012; He et al., 2020), researchers and practitioners started to implement demand management since the 1970s, managing demands for water by institutional approaches and water saving technology, i.e. soft paths such as water pricing, water rights and markets, conservation, and efficiency improvement, etc. (Gleick, 2016; He et al., 2020). In the meantime, a transition from emphasis on managing blue water (surface water and groundwater) to effective utilization of green water (soil water being used to support vegetation growth) has been implemented to holistically improve water use efficiency and ecosystem services (Hoekstra and Mekonnen, 2012).

Since the 1990s, IWRM has been accepted and implemented globally. It calls for systematic consideration of water supplies and water demands, natural and human systems, and upstream and downstream linkages in development and implementation of water resources policies and decisions, as well as stakeholder participation in water resource management processes (Global Water Partnership, 2004; He, 2012; Hering and Ingold, 2012). Despite its global acceptance, IWRM has been criticized for being too broad and vaguely defined and for failing to define and constrain the scope of integration (Johnson et al., 2001; Gourbesville, 2008; Hering and Ingold, 2012). Others cite a mismatch in scales between politics and watersheds and the absence of an 
institutional framework across multiple spatial scales that leads to the failure of achieving sustainable water resources management. They call for a better understanding of multiscale processes of human-environment interactions and implementation of participatory and adaptive management approaches in IWRM (Matondo, 2002; Blomquist and Schlager, 2005; Pahl-Wostl, 2007 ; He, 2012; He et al., 2005, 2010, 2020; Hering and Ingold, 2012; WWAP, 2006, 2019).

\section{Emerging interdisciplinary hydrological sci- ences}

Hydrology is "the science of water", studying the occurrence, distribution, circulation, and properties of water on the earth (NRC, 1991, 2012). Traditionally, the development of hydrological science has focused primarily on water supply and hazard reductions, i.e., issues of engineering hydrology and neglected comprehensive understanding of the global water cycle (NRC, 1991, 2012). Over the past decades, it has evolved to link the atmosphere, land, and oceans to understand the movement of water at all scales and environments and its interaction with climate and life on Earth (NRC, 2012). A number of new subdisciplines have also emerged over the past few decades (NRC, 2012). For example, recognizing the importance of hydrological and ecologic mechanisms and interactions that control ecologic patterns and processes, ecohydrology emerged as one of the scientific frontiers at the beginning of the twenty-first century to study the functional interrelations between hydrology and biota at multiple spatial scales (Zalewski, 2000; Eagleson, 2002; Hannah et al., 2004).

Since the hydrological cycle is a global phenomenon, global hydrology has emerged to study human impacts, water budgets, and other aspects of terrestrial hydrology at the global scale (Bierkens, 2015). A number of global hydrological models have also been developed to model human water demand and human water use, food security, economics, energy, and biodiversity at continental and global scales (Bierkens, 2015). To cope with unprecedent climate and environment changes occurring throughout the world, global-change hydrology has developed as an interdisciplinary field that studies the interactions between the terrestrial water cycle and global change across various time and space scales to understand the natural and anthropogenic causes of the changing terrestrial water cycle and the associated influences and feedbacks in the Earth system (Tang, 2020). Furthermore, as increasing human activities are threating the resilience of the Earth system, a planetary boundary framework has been developed to define, identify and quantify "the safe operating space" of the Earth system and associated biophysical processes by humanity (Rockström et al., 2009; Steffen et al., 2015; Falkenmark et al.,
2019). This framework includes nine planetary boundaries: climate change, stratospheric ozone depletion, ocean acidification, biosphere integrity, biogeochemical flows, landsystem change, freshwater use, atmospheric aerosol loading, and novel entities. It has been applied to detect, monitor, and establish safe limits to water cycle modifications and to water management and governance within both local and global boundaries (Gleeson et al., 2020; Zipper et al., 2020).

Despite the significant advances in hydrological science and related subdisciplines, we are still facing a global water crisis (Johnson et al., 2001; The World Economic Forum, 2013). Worldwide, over 2 billion people have no access to safe drinking water, more than 4 billion people lack access to safely managed sanitation services, and over 3 billion people suffer from recurring floods and droughts (Gleick, 2016; WWAP, 2019; He et al., 2020). The missing link is "the limited effective dynamic interactions between the natural, technical, and social dimensions of human-water systems" (Di Baldassarre et al., 2019). Thus, a new interdisciplinary science, sociohydrology, has been proposed to study the twoway feedbacks between human and water systems around the world and in different contexts to "assist communities involved in IWRM to frame water-related issues in broader terms and develop models capable of generating likely alternative futures under various policy options" (Di Baldassarre et al., 2019).

Others call for the development of an integrated scientific framework to bring different disciplines, sub-basin systems, cutting-edge technologies, multiple databases, and holistic models, stakeholders, scientists, and decision makers together to understand multi-scale processes of human-environment interactions and to support the implementation of Integrated River Basin Management (IRBM) (Matondo, 2002; Pahl-Wostl, 2007; Cai et al., 2015). Unfortunately, watersheds are routinely ignored in water-management programs (Johnson et al., 2001; Hering and Ingold, 2012; Cai et al., 2015). The watershed has been recognized as a basic unit for hydrological research and water resources management among researchers, resource managers and decision/ policy makers (NRC, 1999; He and Croley II, 2010; PulidoVelazquez and Ward, 2017). Therefore, this study proposes that watershed science can be used as the missing link to bridge between hydrological research and water-resources management to support implementation of the UN SDGs at multiple spatial scales.

\section{Watershed science}

The watershed (the area draining into a stream or lake at a given location) has been widely recognized as a basic unit for hydrological research and water resources management (Brady, 1996; USEPA, 1995, 1999; NRC, 1999; Croley II et 
al., 2008; He and Croley II, 2010). As a hydrological system, watershed boundaries span a large range of environments, spatial and temporal scales, from a small tributary with an area of a few hectares to a continental river basin (such as the Mississippi River Basin) of a few million square kilometers over intervals of minutes, hours, and days, to centuries (Paola et al., 2006; Croley II et al., 2008; He and Croley II, 2010). In recent years, the watershed has been the focus of a number of hydrological and earth science programs, e.g., the Critical Zone Observatory (CZO) (Brantley et al., 2007; Cheng et al., 2014; Bogena et al., 2018), the European Union Water Framework Directive (Rahaman et al., 2004), the Consortium of Universities for the Advancement of Hydrologic Science, Inc. (CUAHSI), the Terrestrial Environmental Observations (TERENO) (Zacharias et al., 2011), the Danish Hydrological Observatory (HOBE) (Jensen and Illangasekare, 2011), and the integrated study of the waterecosystem-economy in the Heihe River Basin (Cheng et al., 2014; Li et al., 2015, 2018).

Defining appropriate geographical scales (e.g., watershed, subwatershed, administrative political, or other boundaries) is critical for water resources management (Hering and Ingold, 2012). A mismatch in scales between politics and watersheds leads to a failure to achieve sustainable waterresources management (Matondo, 2002; Blomquist and Schlager, 2005; Hering and Ingold, 2012; Kauffman, 2015). Garrick et al. (2017) proposes a framework to properly recognize, measure, and reconcile the full range of economic, sociocultural, and environmental values of water at multiple temporal and spatial scales, and call for the development of a more inclusive, transparent, and flexible governance architecture to ensure the implementation of policies and management decisions to achieve the UN SDGs. But it remains a challenge to harmonize multiple watersheds and political scales and operationalize the systematic integration of hydrological science and decision/policy making at the watershed scale. Here, we propose watershed science to bridge the missing link between the hydrological science and water resources management.

A few researchers have defined watershed science with different emphases. For example, Cheng et al. (2014) define watershed science as an integrated study of a basin in its totality. They consider the watershed as the best unit for the study of land-surface system science, and propose that the goal of watershed science is to understand and predict the complex behaviors of watershed systems and support sustainable development through optimized configurations of natural resources and human activities (Cheng and Li, 2015). The Department of Watershed Sciences at Utah State University states that its watershed science program offers comprehensive educational opportunities for graduate and undergraduate students in the hydrological and ecologic sciences pertaining to watersheds (https://qcnr.usu.edu/wats, accessed July 7, 2020). Department of Ecosystem Science and Sustainability of Colorado State University describes its watershed science program as "the study of the natural processes and human activities that affect fresh water resources" (https://warnercnr.colostate.edu/ess/about-us/, accessed July 7, 2020). Governance, however, is not included in those definitions of watershed science (WWAP, 2006; Castro, 2007; Grafton et al., 2013; Cai et al., 2015; Kauffman, 2015; Garrick et al., 2017; Di Baldassarre et al., 2019). Here we define watershed science as an interdisciplinary science that studies the interactions between human, socioeconomic, ecologic, geomorphic, and hydrological systems that affect the water cycles in a river basin (Cheng et al., 2014; Li et al., 2015, 2018; Di Baldassarre et al., 2019). It overlaps with and provides a complementary approach to the existing water management programs such as the IWRM. While both the IWRM and watershed science are watershed based, watershed science differs from the IWRM in the following aspects: (1) It explicitly focuses on the storage, fluxes, and quality of the hydrological cycle; (2) it defines appropriate local water-resources thresholds through incorporating the planetary boundary framework; (3) it addresses the scale mismatch problem by harmonizing hydrological and political boundaries; (4) it identifies specific actionable measures for water-resources management at the study watershed.

\section{The framework of watershed science}

A framework has evolved for integrating the hydrological, ecologic, and geomorphic sciences, with government, waterresources management, concepts of sustainability and global change along with other approaches to provide a structure and methodology for integrated watershed sciences. The framework of watershed science includes four main components: (1) hydrological analysis; (2) water-operation policies; (3) governance; (4) management and feedback. The framework attempts to address achieving the UN SDG 6: Ensuring universal availability and sustainable management of water and sanitation for all (UN, 2019). The overall goal of watershed science is to take an interdisciplinary approach to develop science-based processes and solutions for understanding, distributing, and improving the movement and characteristics of water resources to meet the multiple needs of human societies and ecosystems to support sustainable development of a watershed (He et al., 2005, 2020). Specific questions to be addressed include how much water is stored in rivers, lakes, glaciers, soil, aquifers, wetlands, biomass, and riparian systems (Executive Office of the President of the United States, 2004; NRC, 2005, 2012; Grafton et al., 2013)? What are the flux rates and pathways between these components and the atmosphere? How do and how will 
climate change and human activities modify the variability and quality of these water resources over space and time? How to value and prioritize water uses and trade-offs for economic development, ecosystem services, and social equity? How much water should be allocated to what uses, for whom, at what price and for how long? How to define "safe space for humanity" for sustainable water resources management across multiple watershed and political boundaries? What water saving technology should be developed to use water more efficiently and to make more water available? What policies and societal incentives need to be developed to promote the application of water conservation technologies and practices (Executive Office of the President of the United States, 2004)? What forms and mechanisms of decision-making processes should be established to facilitate stakeholder participation and collaborations and to support informed policy/decision making among the federal, state/provincial, and local governmental agencies, nongovernmental organizations and private entities (NRC, 2004; USACE, 2012; Kauffman, 2015)? While no universal answers are available to these questions, these questions should be rationally discussed, debated, and negotiated between multiple stakeholders at federal, state/ provincial, and local levels through proper organizations (e.g., watershed commissions, water districts, water-user associations, and watershed alliances) in a participatory decision-making process. Subsequently, water-management decisions should be implemented, monitored, evaluated, and modified according to changing natural processes and management conditions (He et al., 2000, 2005, 2010, 2020; Hering and Ingold, 2012; Garrick et al., 2017; Zipper et al., 2020). A new water allocation cycle then begins.

\subsection{Hydrological analysis}

A thorough understanding of the quantity and quality of the hydrosphere and hydrological cycle at the study watershed is fundamental for water resources management (He and Croley II, 2007, 2010; Cai et al., 2015; Bierkens, 2015; Garrick et al., 2017). The hydrosphere is a static accounting of water stored in various reservoirs at a given time, whereas the hydrological cycle refers to the dynamic fluxes of water and materials between storage sites through time.

Observation systems and information infrastructure need to be established to provide long-term, high-resolution, consistent, and accurate measurements and information to quantify the variations of hydrosphere and hydrological cycle at multiple spatial and temporal scales. Examples of such observation systems include: The CZO (Brantley et al., 2007), the Heihe Integrated Observatory Network (Li et al., 2013; Cheng et al., 2014; Li et al., 2018), and the Terrestrial Environmental Observations (TERENO) (Zacharias et al., 2011; Bogena et al., 2018). The common features such ob- servation systems share include (1) multi-variate and multiscale observations, (2) adoption of sensor network techniques, (3) use of airborne remote sensing (e.g., unmanned aerial vehicles) to acquire high-resolution datasets, (4) implementation of controlled experiments, and (5) integration of databases, modeling systems, and information systems (Cheng and Li, 2015). The information infrastructure refers to watershed information systems that are able to receive, process, store, and integrate multi-source, multi-resolution, and multi-content databases, and to model and analyze such integrated databases, and in turn generate and visualize the analysis results and transmit them to the relevant users such as water resources researchers, planners, managers, practitioners, and other stakeholders seamlessly (Cheng and Li, 2015; Li et al., 2018).

Through measurements, monitoring, and modeling, the distribution and variations of water from the atmosphere, glaciers, snow-pack, surface runoff, river and lake storage, soil moisture, and groundwater, as well as external supplies of water (transferred and desalinated water) are to be analyzed to quantify the volume, fluxes, and quality of the water across the study watershed. Depending on the water-resources issues in the watershed, the analysis may focus on particular transfers, such as between lakes, rivers, and groundwater, or between the upstream and downstream areas of the watershed. In addition, advancements in remote sensing, tracing and mapping, hydrological modeling, agentbased modeling, machine learning, computing capacity, and analytical methods should be incorporated to quantify fluxes of water from the vegetated areas, glaciers, wetlands, lakes, and soils to understand the impacts of landscape pattern on the hydrological processes in the study watershed ( $\mathrm{He}$ and Croley, 2007, 2010; Famiglietti, 2014; AghaKouchak et al., 2015; Bierkens, 2015; Cai et al., 2015; Jin et al., 2015; Lettenmaier et al., 2015; Paniconi and Putti, 2015; Tian et al., 2017, 2019; Garrick et al., 2017; Kollet et al., 2017; Zhang et al., 2019; Zipper et al., 2020).

\subsection{Water-operation policies}

Hydrological analysis is just the first step to understand the spatial and temporal distribution of the hydrological processes and water resources in the study watershed. To what extent will human activities continue to sustain the water cycles of the study watershed? Or what human actions need to be modified to maintain the water cycles of the watershed? A water planetary boundary framework; i.e., an acceptable level of water operation (e.g., water consumption by agricultural irrigation), can be used to guide sustainable water management and governance and define water-operation policies at watershed or political borders (Gleeson et al., 2020; Zipper et al., 2020). Zipper et al. (2020) developed a cross-scale approach that first computes local water-cycle 
modifications and then compares them to local allocations in the context of global safe-operating space; i.e., local safeoperating boundaries (thresholds) required for sustaining the local water system in stable conditions. The approach can ensure that water cycle modifications remain within both local and global boundaries (Zipper et al., 2020). Since this approach addresses the scale mismatch problem by harmonizing hydrological and political boundaries, it can be used to incorporate the hydroclimatological, ecologic, economic and social variables to define the operation thresholds at the study watershed. The water boundary framework can emphasize sustainability and global change mitigation measures at a variety of scales. The current state of the water system can be compared against the defined thresholds to identify actions for modifying the control variables (e.g., water consumption by irrigation, or water quality by nutrient loading from agricultural land) to bring the hydrological regime within the safe thresholds through water resources planning and management (Zipper et al., 2020).

Climate change, ecologic, economic, and social variables need to be used in comprehensive evaluation of the states of hydrological systems in addition to hydrological criteria. Climate change directly affects variations of water resources and needs to be incorporated into water management processes (Gao et al., 2019; Immerzeel et al., 2020). A better understanding of the relative importance of climate warming and water demand is needed at all scales of analysis. At the global scale, for example, combined use of climate change and water budget models led Vörösmarty et al. (2000) to conclude that increasing demand was likely to be much more important than greenhouse warming to water deficits in 2025. At the national scale, climate simulations have revealed large uncertainties in China's future agricultural security due to potential water shortages (Piao et al., 2010). Given these potential climate-change impacts on water resources, future water availability should not be taken for granted by water-resources planners. Assumptions must be tested with the latest knowledge of climate impacts on both water supply and demand.

Use of water for ecosystem services is an integral part of water resources management (Hering and Ingold, 2012; Garrick et al., 2017; Palmer and Ruhi, 2019; He et al., 2020). Ecosystem-service analysis should define the amount of ecologic benefits that would be produced by allocating and delivering more water for enhancing ecosystem services each year, particularly those intangible services such as soil conservation, desertification control, reduction of sand storms, flood management, watershed protection, habitat provision, water and air quality improvement, etc. (Kinzig et al., 2011; Garrick et al., 2017). This analysis should include benefits from water allocated for environmental purposes, such as maintaining biodiversity, which is often omitted from conventional valuations.
Economic analysis is needed to address the benefits and costs of the water-management decisions for upstream and downstream users, and for the whole watershed. For example, if water users upstream reduce withdrawals in order to deliver more water for downstream users, or take conservation measures to reduce soil erosion and nutrient loading such as phosphorus and nitrogen downstream, how much cost (economic loss) would they bear and how much benefit is to be gained by the downstream users? Are the aggregate benefits from the water allocation greater than the costs over the entire watershed (He et al., 2000; Kinzig et al., 2011)? What criteria are to be used to evaluate the trade-offs among different water uses, such as water withdrawals for agricultural irrigation vs maintaining water in the river or lake for fisheries or aquatic habitat? Since water is undervalued in the world (Johnson et al., 2001), economic analysis should take into account the full costs of supplying and distributing water and the cost of integrated watershed management (Gleick, 2016; Garrick et al., 2017; He et al., 2020).

Social analysis should identify who benefits and who loses from the water management decisions and proposes fair compensation for those water users who take an economic loss. For example, if the upstream water users are to be compensated for delivering more water downstream for rehabilitation of the downstream ecosystem, how should they get compensated and who pays for that, downstream water users or governmental entities (Johnson et al., 2001; PahlWostl, 2007; Hering and Ingold, 2012; Hoekstra and Mekonnen, 2012; Garrick et al., 2017). How much funding should be allocated to provide universal access to safe and clean drinking water supply and sanitation services to all the residents in the study watershed? Social considerations also include ethical, political, and legal concerns such as property ownership, jurisdiction, and water allocation rights.

\subsection{Governance}

The global water crisis is a governance crisis (WWAP, 2006; Castro, 2007; Grafton et al., 2013; Kauffman, 2015; Garrick et al., 2017; Di Baldassarre et al., 2019). Implementation of water management decisions involves formation of watershed organizations, data sharing, stakeholder participation and management of the water operation plans.

(i) Formation of watershed organizations

As watersheds often operate across multiple administrative jurisdictions, proper forms of organizations can be established to address important watershed-scale issues such as water allocation among the upstream and downstream water users. Examples of such organizations are water-user associations (e.g., irrigation-user associations in China), watermanagement districts (e.g., in the State of Florida in the U.S.), or river-basin commissions (e.g., the Yellow River 
Conservancy Commission or YRCC in China and the Delaware River Basin Commission in the U.S.), regional authorities (Tennessee Valley Authority or TVA in the U.S.) (Christian-Smith et al., 2012; USACE, 2012; Garrick et al., 2017; He et al., 2000, 2020).

\section{(ii) Data sharing}

Data sets of climate, hydrology, aquifers, land use, socioeconomics, demography, water uses, and ecosystem services are "the lifeblood" of the hydrological sciences and water resources management (Bierkens, 2015). Such data should be shared among all the stakeholders in the study watershed to facilitate participation in and to support informed watershed decision making. Over the past decades, multiple physical and socioeconomic datasets have been collected globally, but accessibility and availability of such datasets vary, especially in many of the developing countries. In particular, long-term, consistent, and high-resolution wateruse and operation data are currently not available at watershed and regional scales, for example, agricultural and ecosystem uses of water at watershed or subwatershed scales, water diversions, reservoir operations, groundwater withdraws and quality, and aquatic habitat (Bierkens, 2015). Development of information infrastructure for systematic collection, compilation, processing, analysis, visualization, and dissemination of these data sets across multiple scales would enhance science-based, participatory watershed management (Garrick et al., 2017).

(iii) Stakeholder participation

Implementation of a water-management plan requires close interactions and strong partnerships among all stakeholders, such as federal, state/provincial, and local governments, industry, residents, property owners, community groups, and the research community (WWAP, 2006; Garrick et al., 2017; He et al., 2000, 2020). The water-management plan should be discussed, debated, revised, and agreed upon among those stakeholders through a participatory decisionmaking process to ensure the successful implementation of the plan at the watershed scale. The Colorado River Conversations initiative in the southwestern United States is a good example of stakeholder participation in water resources decision making process.

The Colorado River, covering portions of seven states of the United States-Wyoming, Utah, Colorado, Nevada, New Mexico, California, and Arizona, part of Mexico, and 34 Indian reservations, has a drainage area of about $647,000 \mathrm{~km}^{2}$ and serves over 40 million people in the southwestern United States (He et al., 2020). Over the past few decades, the warming climate, multiple, competing water uses, large storage capacities of the dams and reservoirs, and diversions in the Lower Basin stop the river from flowing to the Gulf of California in most years, negatively affecting the bilateral relationships between the United States and Mexico, as well as environmental conditions of the delta region (He et al., 2020). To prepare for completion of the renegotiation of the current guidelines, the Colorado River Interim Guidelines for Lower Basin Shortage and Coordinated Operation for Lake Powell and Lake Mead by 2026, the Center for Climate Adaptation Science and Solutions (CCASS) at the University of Arizona had hosted three interdisciplinary conferences and a three-phase scenario planning process to discuss a range of science and policy topics related to managing the river under a broader Colorado River Conversations (CRC) initiative during the period of 2017 to 2019 (Jacobs et al., 2020). Participants in these events included representatives of all seven Colorado River basin states, two Mexican states, multiple Native American tribes, academics, scientists, water managers, agricultural producers, environmentalists, and others. They identified gaps in scientific knowledge, including groundwater interactions, ecosystem structure and function, sediment management, power production trade-offs, etc., and explored extreme events ("nightmare") scenarios. Trough open and interactive debates and discussions, they proposed creative, out of box, solutions to the intertwining water resources, ecosystem services, economic growth, and regional development issues. The project created a platform to bring multiple stakeholders together to start dialogue and mutual understanding. It also demonstrates the potential of this flexible scenario planning approach to informed decision making processes across other contexts and regions (Jacobs et al., 2020).

(iv) Management and feedback

A management mechanism can be developed through the watershed organization (e.g., the Yellow River Conservancy Commission) for operating, monitoring, evaluating, and modifying a water-management plan among agricultural, industrial, municipal, and ecosystem users (He et al., 2000; Hering and Ingold, 2012; Garrick et al.,2017). Multiple data sets of hydrology, land use, ecosystem, and social economics may need to be systematically collected through a scientifically designed monitoring plan over the entire watershed. Subsequently, these data are used to compute and compare values of the hydrological, ecologic, and socio-economic variables for evaluation of the performance of the watermanagement plan for upstream and downstream users as well as for the entire watershed. If comparison of the hydrological, ecologic, and socio-economic indicators between pre- and post-implementation of the plan shows improvements and meets the safe operating space (water-operation policies) defined by the water planetary boundary framework, then the management plan is able to meet the competing demands for water among the upstream and downstream users and stays within the safe operating thresholds by the water-operation policies in Step 2 of the Framework of Watershed Science. Otherwise, the management plan is either unable to bring the anticipated compre- 
hensive benefits to the watershed as a whole, or the conflicts are not alleviated (e.g., conflicts between upstream and downstream users). New or additional management strategies are needed to alleviate the conflicts.

Water saving technologies are essential in water resources management, especially in arid regions. Globally, at least half of the water withdrawn for irrigation is wasted. If the wasted water is fully used by crops, doubling the current global food production could be achieved without additional water withdrawals (He et al., 2014). Implementation of optimal irrigation schedule could save over half of the irrigation amount at the current practices over a 5-year precipitation cycle in the arid Heihe River Basin, Northwest China (Jiang et al., 2016).

When substantial modifications need to be made to the water management plan, a new water-management cycle begins (He et al., 2000; NRC, 2004; Engle et al., 2011; USACE, 2012; WWAP, 2006, 2017, 2019; Zipper et al., 2020). Munia et al. (2020) report that changes in upstream water availability influences downstream net water availability. Reduced water availability for downstream users due to increasing demand by upstream users can be managed through negotiations between upstream and downstream users. However, changes in the upstream availability caused by climate change (e.g., droughts and floods) requires adaptation strategies beyond local water management (Munia et al., 2020).

\section{Challenges and opportunities for watershed science}

Watershed science overlaps with and provides a complementary approach to the existing water management programs such as the IWRM. It also differs from those programs with the following unique characteristics: (1) It integrates measurements, monitoring, and modeling, and explicitly quantifies the storage, fluxes, and quality of the hydrological cycle over multiple scales. (2) It incorporates the water planetary boundary framework, hydroclimatological, ecologic, and socio-economic variables to define the local operation thresholds at the study watershed. (3) It addresses the scale mismatch problem by harmonizing hydrological and political boundaries. (4) It identifies specific actionable measures for water-resources management within the study watershed. (5) It calls for formation of watershed organizations to establish a mechanisms for active interactions and strong partnerships among all stakeholders such as governments, industry, residents, property owners, community groups, and the research community to ensure stakeholder participation and management of water management plans.

While the focus of water resources management might differ between arid watersheds (where water availability and quality are priorities) and humid watersheds (where water pollution and flood management are priorities) (He et al., 2014), the watershed science approach applies to both humid and arid watersheds. For example, control of soil erosion and reduction of nutrient loading to water bodies require identification, tracking, monitoring, and analysis of sources, fluxes and pathways of sediments and nutrients, determination of the local operation thresholds, development of specific actionable measures, and cooperation and participation of upstream and downstream stakeholders through a watershed organization (e.g. watershed council) for implementation of sediment and nutrient reduction plans at the study watershed (He et al., 2010, 2014, 2020).

The main challenges in WS are: (1) Establishment of observation systems for systematic collection of long term, consistent, high-resolution water-use and water-quality data at tributary, subwatershed and watershed scales; (2) bringing researchers, practitioners and resources managers from multiple disciplines of climate, hydrology, ecology, demography, economics, sociology, and management sciences together to define the local water-operation policies at the study watershed; (3) formation of stakeholder participation platforms to ensure active and effective interactions among governments, industry, residents, community groups, and the research community for dynamic management of the water management plans in the study watershed, particularly in societies dominated by top-down policy development approaches (Engle et al., 2011; He et al., 2010, 2014, 2020).

Despite these challenges, recent developments and advancements in science, remote sensing, tracing and mapping, hydrological modeling, computing capacity, and analytical methods have created opportunities for watershed science. Many in-situ observations and databases of climate, hydrology, river network, reservoirs and dams, land cover, soil moisture, groundwater, agriculture, irrigation, carbon and energy fluxes, as well as hyper-resolution remote sensing are being systematically collected, processed, and disseminated to users over information systems (e.g., internet and cloud computing) (He and Croley II, 2007; Li et al., 2013; Cheng and $\mathrm{Li}, 2015)$. Water-use data, such as agricultural irrigation and ecosystem uses of water are increasingly collected at multiple spatial scales (Bierkens, 2015; Lettenmaier et al., 2015; Dieter et al., 2018; He et al., 2014, 2020). Enhanced interactions and synergies among scholars, researchers, and practitioners in climate science, hydrological science, ecology, sociology, economics, computer and information science, and management science, etc. have significantly improved the simulation and prediction capability of watercycle dynamics over multiple spatial and temporal scales, and successfully defined safe water-operating policies to sustain both the local and global water boundaries (Vörösmarty et al., 2000; Piao et al., 2010; Zipper et al., 2020). 


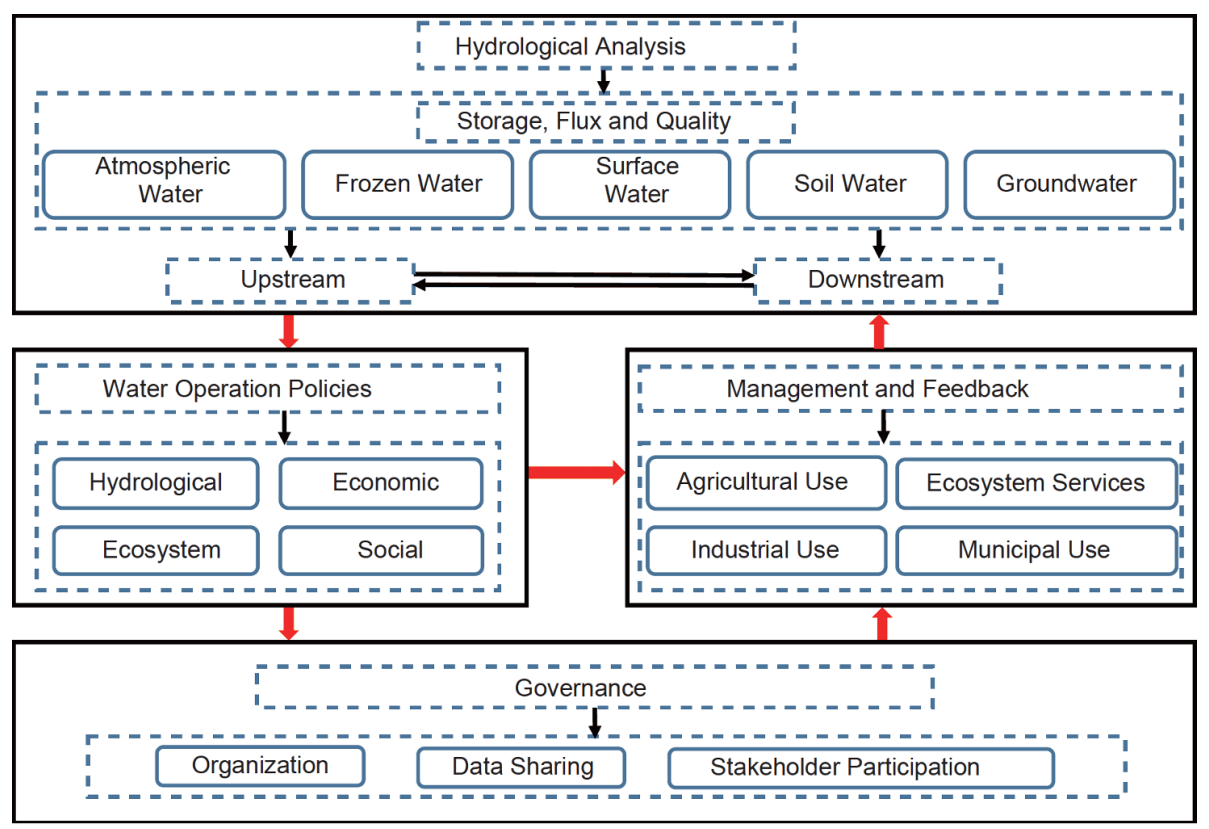

Figure 1 (Color online) Framework of watershed science, modifications of works by He (2012), Garrick et al. (2017), and Zipper et al. (2020).

Watershed-based water resource management programs have been widely implemented globally. River basin governance, while varying in structure and authority, ranges from regional (e.g., TVA), to multi-state watershed councils (e.g., the YRCC), to water management districts (e.g., South Florida Water District in the U.S.) and provides platforms for adaptive, stakeholder participatory decision making. Such adaptive decision-making processes have and continue to achieve significant effects in management and rehabilitation of watersheds across the world (USEPA, 1995, 1999; NRC, 1999, 2004; Engle et al., 2011; He et al., 2020; Jacobs et al., 2020). For example, in the Colorado River, multiple federal, tribal, state, and local governments work together to rehabilitate river ecosystems to comply with the Endangered Species Act (He et al., 2020). The broader Colorado River Conversations (CRC) initiative attracted participants from all seven Colorado River basin states, two Mexican states, multiple Native American tribes, academics, scientists, water managers, agricultural producers, environmentalists, and others to identify gaps in scientific knowledge, explore extreme events scenarios, and propose creative solutions to intertwining water resources, ecosystem services, economic growth, and regional development issues during the period of 2017 to 2019 (Jacobs et al., 2020). In the Yellow River Basin since 2000, the Yellow River Conservation Commission has led a well-coordinated effort among the central, provincial, and local governments in successfully implementing largescale ecological restoration programs such as "Grain for Green" and "Northern China's Vegetation Belt" to rehabilitate ecosystem services, dramatically reducing the sediment load from $\sim 1.6$ billion tonnes/year in the 1970s to $\sim 0.3$ billion tonnes/year at present ( $81 \%$ reduction), leading to increased soil carbon storage and net primary productivity (He et al., 2020). All these advancements and examples indicate great potential for application of watershed science in addressing the global water crisis.

\section{Application of watershed science}

A good example of implementation of watershed science is a large scale, multiple-year research program in China, "The integrated research on the eco-hydrological process of the Heihe River Basin" launched by the National Science Foundation of China (NSFC) in 2007 (Cheng et al., 2014; Song, 2019). The Heihe River Basin (HRB), the second largest inland river basin (terminal lake) in China with a drainage area of about $143,000 \mathrm{~km}^{2}$, was selected as an ideal testbed of the integrated watershed research method due to its diverse landscapes, unique land-surface processes, complex water cycles, and intensifying water conflicts among the upstream and downstream users (Cheng et al., 2014; Li et al., 2018). The integrated research project aims to: (1) understand the mechanisms and interactions of hydrological and ecologic processes at the watershed scale, (2) develop a watershed eco-hydrological model, and (3) implement a decision-support system for enhanced analysis and prediction of the variability of the hydrological, ecologic, and economic systems for sustainable use of the water resources in the Heihe River Basin (Cheng et al., 2014; Song, 2019). The project is observation-based; multi-scale, extensive by covering from patch, to tributary, to watershed scales, and 
interdisciplinary, by interacting among over 150 participating institutions across hydrological, ecologic, economic, and management sciences. The project has significantly advanced the integration of watershed-scale observation-data and ecologic-hydrological models and an innovative combination of "natural process" and "social learning" in watershed research. So far, a 3M (i.e., monitoring, modeling, and data manipulation) integration platform has been put in place to support the development of a fully integrated waterecosystem-economy model and a spatially explicit decisionsupport system (DSS) for the sustainable development of the HRB (Cheng et al., 2014; Li et al., 2018; Song, 2019). However, despite the significant advancements in the current observatories, models and data platforms during the past two decades, incorporation of group decision-making processes by various stakeholders, including government agencies, experts, and local residents, has yet to be fully integrated into the current decision-support system (Song, 2019). The process of linking researchers and decision makers is often timeconsuming, less effective or even cumbersome, falling outside the traditional research disciplines, and long but less rewarding research cycle (Pahl-Wostl, 2007; Engle et al., 2011; Cai et al., 2015).

Watershed science offers an alternative mechanism of promoting interactions between science and management to support informed decision making in water resources management and sustainable development. This process may involve two phases: The creation phase and the implementation phase (He et al., 2000). In the creation phase, an organization such as a watershed council may invite a small number of researchers, representatives from governmental agencies, private entities and citizens to form a focus group to guide and coordinate the effective inclusion of watershed research and variables in watershed planning, management, and stakeholder participation in decision making. This main tasks include (1) development of an initial vision and set of goals, (2) preliminary assessment of watershed problems and opportunities, and (3) identification of key stakeholders and solicitation of their participation in watershed planning process (He et al., 2000). Subsequently, in the implementation phase, the larger stakeholder group formed in the creation phase builds on the preliminary assessments and findings to focus on the research and the types of variables that are needed for effective planning, management, and policy making. The tasks include (1) developing an initial vision and set of goals based on the broad watershed outcomes, (2) identifying main problems in water resources planning and management as well as responses to climate change and extreme events, (3) assessing resources, challenges, and opportunities available in the study watershed, (4) building the organization or network for watershed planning and management, (5) developing goals and recommendations for research, indicator development and refinement, as well as management plans, and (6) establishing an ongoing set of procedures for operation and evaluation of watershed planning and management to support sustainable regional development (He et al., 2000, 2020; Jacobs et al., 2020).

While water resources decisions still dominantly reside with the central government agencies in China, such a general process has gradually been applied to China's water resources management. In recent years, solicitation of participation of key stakeholders (e.g., county government agencies and local residents) in the water planning process is often achieved through systematic interactions such as meetings (e.g., public hearings), surveys, and discussions with relevant stakeholders (Engle et al., 2011; He et al., 2000, 2020). This form of public participation needs to be further expanded to incorporate multiple needs of the upper, middle, and lower reach users in the watershed planning and management. This participatory and interactive planning approach will not only improve our understanding of the interactions among human, socioeconomic, physical, hydrological, and ecologic processes in the study watersheds, but will also facilitate the interaction between research and management communities in integrating scientific data and information into participatory watershed decision making processes (NRC, 2004; Pahl-Wostl, 2007; Engle et al., 2011; Cai et al., 2015; He et al., 2000, 2020). In the particular case of the Heihe River Basin, much data and analyses have been conducted. Much hydrological, ecologic, economic, and social data have been collected and analyzed to quantify the storage and fluxes of atmospheric water, glacier and snowpack, surface water, soil water, and groundwater (Step 1). Integrating monitoring, modeling and data manipulation and collaborating with multiple research teams, a fully integrated water-ecosystem-economy model and a spatially explicit decision-support system (DSS) have been put in place to identify, simulate and predict land management scenarios to define the water operation policies (Step 2). An agent-based model (ABM) was developed to simulate farmers' decisionmaking on conjunctive use of groundwater and surface water under the influence of policy portfolio with collective water management policies (Du et al., 2020). Such management scenarios include recommendation of modification of crop pattern in the middle reach oasis area, water exchange through market mechanisms among water users in the middle reach area to promotes efficient and beneficial water uses, approval of a proposed water allocation plan in the HRB to deliver 0.95 billion $\mathrm{m}^{3}$ of water downstream annually for ecosystem rehabilitation by the State Council of China to address the downstream water shortages (Cheng et al., 2014; Li et al., 2018; Song, 2019; He et al., 2020). These results have established a solid foundation for incorporation of participatory planning approach discussed above to generate synergies among research, management and water user 
communities to support sustainable development of the HRB. As discussed above, multiple stakeholders from local (e.g., irrigation districts) and regional watershed organizations (e.g., the Bureau of the Heihe River Administration), research community (universities and research institutions), and private entities and citizens (e.g., agricultural water user associations, industrial water user associations, and local residents) should come together to form an organization or network for watershed planning and management. These groups should continue to be coordinated and integrated with local and national governments to review and discuss the research results and indicators developed in Steps 1 and 2. They will debate and explore responses/solutions to the key questions such as: How much water can be used and allocated to municipal supply, industry, agriculture and ecology? At what price and who pays for such uses? What policies, best water saving technologies and management practices are needed to maintain water operation thresholds across multiple watershed and political boundaries (Step 3)? Through this interactive planning process, water allocation and management scenarios evolve to support water resources planning and decision making. Subsequently, the watershed management plans and policies that arise from these efforts should be evaluated under this systematic approach (Step 4). Multiple data sets of hydrology, land use, ecosystem, and social economics need to be systematically collected to compute and compare values of the hydrological, ecologic, and socio-economic variables for evaluation of the performance of the water-management plan for upstream and downstream users as well as for the entire watershed. If comparison of the hydrological, ecologic, and socio-economic indicators between pre- and post-implementation of the plan shows improvements and meets the safe water-operation space, then the management plan is able to meet the competing demands for water among the upstream and downstream users and stays within the safe operating thresholds. Otherwise, the management plan needs to be revised to alleviate the water resources problems. A new water planning cycle begins.

\section{Summary}

This study reviews the development of hydrological sciences and water resources management over the past few decades and states that the missing link is effective interactions between science and decision-making in watershed research. Subsequently, the study proposes to develop watershed science to complement the existing water resources management programs. The core components of the watershed science include: (1) hydrological analysis, (2) water-operation policies, (3) governance, and (4) management and feedback. The integrated research on the eco-hydrological process of the Heihe River Basin is shown as an implementation example of the watershed science.

From the perspective of Earth system science, Cheng and Li (2015) described a set of research methods of watershed science, including the self-organized complex system method, the upscaling method, selection and evolutionary principles, hydro-economic and eco-economic methods that emphasize the human-nature system co-evolution, and metasynthesis for addressing unstructured problems. These and other emerging methods such as artificial intelligence (AI) aided design and learning are certainly important part of watershed science. This study, however, focuses the framework of watershed science and serves as "the food for thought" for further discussions and suggestions for improving and refining the watershed science.

Watershed science studies the interactions between human, socioeconomic, ecologic, geomorphic, and hydrological systems that affect the water cycles in a river basin. It directly addresses water supply and water quality, two of the UN SDGs (Goal \#6: Clean water and sanitation and Goal \#14: Life below water) that specifically target water resources (UN, 2019; He et al., 2020). In addition, it takes a holistic approach to develop science-based processes and solutions for understanding, distributing, and improving the movement and characteristics of water resources to meet the multiple needs of human societies and ecosystems to support sustainable development of a watershed. Such an approach is critical for agricultural production and food supply (Goal \#2: Zero hunger), affordable and clean energy (Goal \#7), and life on land (Goal \#15). Watershed science emphasizes effective water governance that builds institutional relationships and partnerships (Goal \#17: Partnerships for the goals), promotes participatory decision making in water resources management that is closely related to peace, justice, and strong institutions (Goal \#16), and supports efforts to achieve responsible consumption and production (Goal \#12) (He et al., 2020). Together, these efforts contribute to alleviating poverty (Goal \#1) and creating sustainable cities and communities (Goal \#11) (UN, 2019; He et al., 2020).

Acknowledgements This work was supported by the National Natural Science Foundation of China (Grant Nos. 42030501, 41530752, and 91125010), and the Scherer Endowment Fund of Department of Geography, Western Michigan University.

Open Access This article is licensed under a Creative Commons Attribution 4.0 International License, which permits use, sharing, adaptation, distribution and reproduction in any medium or format, as long as you give appropriate credit to the original author(s) and the source, provide a link to the Creative Commons licence, and indicate if changes were made. The images or other third party material in this article are included in the article's Creative Commons licence, unless indicated otherwise in a credit line to the material. If material is not included in the article's Creative Commons licence and your intended use is not permitted by statutory regulation or 
exceeds the permitted use, you will need to obtain permission directly from the copyright holder. To view a copy of this licence, visit http://creativecommons.org/licenses/by/4.0/.

\section{References}

AghaKouchak A, Feldman D, Hoerling M, Huxman T, Lund J. 2015. Water and climate: Recognize anthropogenic drought. Nature, 524: 409-411

Bierkens M F P. 2015. Global hydrology 2015: State, trends, and directions. Water Resour Res, 51: 4923-4947

Blomquist W, Schlager E. 2005. Political pitfalls of integrated watershed management. Soc Nat Resour, 18: 101-117

Bogena H R, White T, Bour O, Li X, Jensen K H. 2018. Toward better understanding of terrestrial processes through long-term hydrological observatories. Vadose Zone J, 17: 180194

Brady D J. 1996. The watershed protection approach. Water Sci Tech, 33: $17-21$

Brantley S L, Goldhaber M B, Ragnarsdottir K V. 2007. Crossing disciplines and scales to understand the critical zone. Elements, 3: 307-314

Cai X M, Marston L, Ge Y C. 2015. Decision support for integrated river basin management-Scientific research challenges. Sci China Earth Sci, 58: 16-24

Castro J E. 2007. Water governance in the twentieth-first century. Ambient Scocietdad, 10: 97-118

Cheng G D, Li X. 2015. Integrated research methods in watershed science. Sci China Earth Sci, 58: 1159-1168

Cheng G D, Li X, Zhao W Z, Xu Z M, Qi F, Xiao S C, Xiao H L. 2014. Integrated study of the water-ecosystem-economy in the Heihe River Basin. Natl Sci Rev, 1: 413-428

Christian-Smith J, Gleick P, Cooley H, Vanderwarker A, L Allen, Berry K A. A Twenty-first Century US Water Policy. New York: Oxford University Press, 2012

Croley II T E, Raikow D F, He C S, Atkinson J F. 2008. Hydrological resource sheds. J Hydrol Eng, 13: 873-885

Di Baldassarre G, Sivapalan M, Rusca M, Cudennec C, Garcia M, Kreibich H, Konar M, Mondino E, Mård J, Pande S, Sanderson M R, Tian F Q, Viglione A, Wei J, Wei Y P, Yu D J, Srinivasan V, Blöschl G. 2019. Sociohydrology: Scientific challenges in addressing the sustainable development goals. Water Resour Res, 55: 6327-6355

Dieter C A, Maupin M A, Caldwell R R, Harris M A, Ivahnenko T I, Lovelace J K, Barber N L, Linsey K S. 2018. Estimated use of water in the United States in 2015. In: US Geological Survey Circular 1441. 65

Du E, Tian Y, Cai X M, Zheng Y, Li X, Zheng C M. 2020. Exploring spatial heterogeneity and temporal dynamics of human-hydrological interactions in large river basins with intensive agriculture: A tightly coupled, fully integrated modeling approach. J Hydrol, 591: 125313

Eagleson P S. 2002. Ecohydrology: Darwinian Expression of Vegetation Form and Function. Cambridge: Cambridge University Press, 2002

Engle N L, Johns O R, Lemos M C, Nelson D R. 2011. Integrated and adaptive management of water resources: Tensions, legacies, and the next best thing. Ecol Soc, 16: 19

Executive Office of the President of the United States. 2004. Science and Technology to Support Fresh Water Availability in the United States. Technical Report. Washington DC: the National Science and Technology Council (U.S.), Committee on Environment and Natural Resources

Falkenmark M, Wang-Erlandsson L, Rockström J. 2019. Understanding of water resilience in the Anthropocene. J Hydrol X, 2: 100009

Famiglietti J S. 2014. The global groundwater crisis. Nat Clim Change, 4: 945-948

Gao J, Yao T, Masson-Delmotte V, Steen-Larsen H C, Wang W. 2019. Collapsing glaciers threaten Asia's water supplies. Nature, 565: 19-21

Garrick D E, Hall J W, Dobson A, Damania R, Grafton R Q, Hope R, Hepburn C, Bark R, Boltz F, De Stefano L, O’Donnell E, Matthews N, Money A. 2017. Valuing water for sustainable development. Science, 358: $1003-1005$
Gleeson T, Wang-Erlandsson L, Porkka M, Zipper S C, Jaramillo F, Gerten D, Fetzer I, Cornell S E, Piemontese L, Gordon L J, Rockström J, Oki T, Sivapalan M, Wada Y, Brauman K A, Flörke M, Bierkens M F P, Lehner B, Keys P, Kummu M, Wagener T, Dadson S, Troy T J, Steffen W, Falkenmark M, Famiglietti J S. 2020. Illuminating water cycle modifications and Earth system resilience in the Anthropocene. Water Resour Res, 56: e24957

Gleick P H. 2016. Water strategies for the next administration. Science, 354: $555-556$

Gleick P H, Allen L, Christian-Smith J, Cohen M J, Cooley H, Heberger M, Morrison J, Palaniappan M, Schulte P. 2012. The World's Water Volume 7. The Biennial Report on Freshwater Resources. Washington DC: Island Press. 440

Global Water Partnership. 2004. Catalyzing Change: A Handbook for Developing Integrated Water Resources Management (IWRM) and Water Efficiency Strategies. Stockholm, Sweden. http://hdl.handle.net/ $10535 / 5032$

Gourbesville P. 2008. Challenges for integrated water resources management. Phys Chem Earth Parts A/B/C, 33: 284-289

Grafton R Q, Pittock J, Davis R, Williams J, Fu G, Warburton M, Udall B, McKenzie R, Yu X, Che N, Connell D, Jiang Q, Kompas T, Lynch A, Norris R, Possingham H, Quiggin J. 2013. Global insights into water resources, climate change and governance. Nat Clim Change, 3: 315321

Hannah D M, Brown L E, Milner A M, Gurnell A M, McGregor G R, Petts G E, Smith B P G, Snook D L. 2007. Integrating climate-hydrologyecology for alpine river systems. Aquat Conserv: Mar Freshw Ecosyst, 17: 636-656

Hannah D M, Wood P J, Sadler J P. 2004. Ecohydrology and hydroecology: A 'new paradigm'? Hydrol Process, 18: 3439-3445

He C, Cheng S K, Luo Y. 2005. Desiccation of the Yellow River and the south water northward transfer project. Water Int, 30: 261-268

He C, Croley II T E. 2007. Application of a distributed large basin runoff model in the Great Lakes Basin. Control Eng Practice, 15: 1001-1011

He C, Croley II T E. 2010. Hydrological resource sheds and the U.S. Great Lakes applications. J Resour Ecol, 1: 25-30

He C, Harden C P, Liu Y. 2020. Comparison of water resources management between China and the United States. Geogr Sustain, 1: 98108

He C, He X, Fu L. 2010. China's South-to-North water transfer project: Is it needed? Geogr Compass, 4: 1312-1323

He C, Malcolm S B, Dahlberg K A, Fu B. 2000. A conceptual framework for integrating hydrological and biological indicators into watershed management. Landsc Urban Plann, 49: 25-34

He C, Zhang L, Zhang X, Eslamian S. 2014. Chapter 28: Water security: Concept, measurement, and operationalization. In: Eslamian S, ed. Handbook of Engineering Hydrology. New York: CRC Press. 544-555

He C S. 2012. Water resource management and watershed science (in Chinese). Adv Earth Sci, 27: 705-711

Hering J G, Ingold K M. 2012. Water resources management: What should be integrated? Science, 336: 1234-1235

Hoekstra A Y, Mekonnen M M. 2012. The water footprint of humanity. Proc Natl Acad Sci USA, 109: 3232-3237

Immerzeel W W, Lutz A F, Andrade M, Bahl A, Biemans H, Bolch T, Hyde S, Brumby S, Davies B J, Elmore A C, Emmer A, Feng M, Fernández A, Haritashya U, Kargel J S, Koppes M, Kraaijenbrink P D A, Kulkarni A V, Mayewski P A, Nepal S, Pacheco P, Painter T H, Pellicciotti F, Rajaram H, Rupper S, Sinisalo A, Shrestha A B, Viviroli D, Wada Y, Xiao C, Yao T, Baillie J E M. 2020. Importance and vulnerability of the world's water towers. Nature, 577: 364-369

Jacobs K, McCoy A, Martin S, Gerlak A. 2020. Reimagining the Colorado River by exploring extreme events. Eos, 101, http://doi.org/10.1029/ 2020EO151369

Jensen K H, Illangasekare T H. 2011. HOBE: A hydrological observatory. Vadose Zone J, 10: 1-7

Jiang Y, Zhang L, Zhang B, He C, Jin X, Bai X. 2016. Modeling irrigation management for water conservation by DSSAT-maize model in arid 
northwestern China. Agric Water Manage, 177: 37-45

Jin X, Zhang L, Gu J, Zhao C, Tian J, He C. 2015. Modelling the impacts of spatial heterogeneity in soil hydraulic properties on hydrological process in the upper reach of the Heihe River in the Qilian Mountains, Northwest China. Hydrol Process, 29: 3318-3327

Johnson N, Revenga C, Echeverria J. 2001. ECOLOGY: Managing water for people and nature. Science, 292: 1071-1072

Kauffman G J. 2015. Governance, policy, and economics of intergovernmental river basin management. Water Resour Manage, 29: 5689-5712

Kinzig A P, Perrings C, Chapin III F S, Polasky S, Smith V K, Tilman D, Turner II B L. 2011. Paying for ecosystem services—Promise and peril. Science, 334: 603-604

Kollet S, Sulis M, Maxwell R M, Paniconi C, Putti M, Bertoldi G, Coon E T, Cordano E, Endrizzi S, Kikinzon E, Mouche E, Mügler C, Park Y J, Refsgaard J C, Stisen S, Sudicky E. 2017. The integrated hydrologic model intercomparison project, IH-MIP2: A second set of benchmark results to diagnose integrated hydrology and feedbacks. Water Resour Res, 53: 867-890

Lettenmaier D P, Alsdorf D, Dozier J, Huffman G J, Pan M, Wood E F. 2015. Inroads of remote sensing into hydrologic science during the WRR era. Water Resour Res, 51: 7309-7342

Li X, Cheng G D, Liu S M, Xiao Q, Ma M G, Jin R, Che T, Liu Q H, Wang W Z, Qi Y, Wen J G, Li H Y, Zhu G F, Guo J W, Ran Y H, Wang S G, Zhu Z L, Zhou J, Hu X L, Xu Z W. 2013. Heihe Watershed allied telemetry experimental research (HiWATER): Scientific objectives and experimental design. Bull Am Meteorol Soc, 94: 1145-1160

Li X, Cheng G D, Ge Y C, Li H Y, Han F, Hu X L, Tian W T, Tian Y, Pan X D, Nian Y Y, Zhang Y L, Ran Y H, Zheng Y, Gao B, Yang D W, Zheng C M, Wang X S, Liu S M, Cai X M. 2018. Hydrological cycle in the Heihe River Basin and its implication for water resource management in endorheic basins. J Geophys Res Atmos, 123: 890-914

Li X, Zhang G L, He C S. 2015. Watershed science: Bridging new advances in hydrological science with good management of river basins. Sci China Earth Sci, 58: 1-2

Matondo J I. 2002. A comparison between conventional and integrated water resources planning and management. Phys Chem Earth Parts A/B/ C, 27: 831-838

Munia H A, Guillaume J H A, Wada Y, Veldkamp T, Virkki V, Kummu M. 2020. Future transboundary water stress and its drivers under climate change: A global study. Earth's Future, 8: e01321

NRC (National Research Council). 1991. Opportunities in the Hydrologic Sciences. Washington DC: The National Academies Press

NRC (National Research Council). 1999. New Strategies for America's Watersheds. Washington DC: The National Academy Press

NRC (National Research Council). 2004. Adaptive Management for Water Resources Project Planning. Washington DC: The National Academies Press

NRC (National Research Council). 2005. The Science of Instream Flows: A Review of the Texas Instream Flow Program. Washington DC: The National Academies Press

NRC (National Research Council). 2012. Challenges and Opportunities in the Hydrologic Sciences. Washington DC: The National Academies Press

Pahl-Wostl C. 2007. The implications of complexity for integrated resources management. Environ Model Software, 22: 561-569

Palmer M, Ruhi A. 2019. Linkages between flow regime, biota, and ecosystem processes: Implications for river restoration. Science, 365: eaaw2087

Paniconi C, Putti M. 2015. Physically based modeling in catchment hydrology at 50: Survey and outlook. Water Resour Res, 51: 7090-7129

Paola C, Foufoula-Georgiou E, Dietrich W E, Hondzo M, Mohrig D, Parker G, Power M E, Rodriguez-Iturbe I, Voller V, Wilcock P. 2006. Toward a unified science of the Earth's surface: Opportunities for synthesis among hydrology, geomorphology, geochemistry, and ecology. Water Resour Res, 42: W03S10

Piao S L, Ciais P, Huang Y, Shen Z H, Peng S S, Li J S, Zhou L P, Liu H Y, Ma Y C, Ding Y H, Friedlingstein P, Liu C Z, Tan K, Yu Y Q, Zhang T Y, Fang J Y. 2010. The impacts of climate change on water resources and agriculture in China. Nature, 467: 43-51

Pulido-Velazquez M, Ward F A. 2017. Comparison of water management institutions and approaches in the United States and Europe-What can we learn from each other? In: Competition for Water Resources: Experiences and Management Approaches in the US and Europe. Amsterdam: Elsevier Inc. 423-441

Rahaman M M, Varis O, Kajander T. 2004. EU water framework directive vs. integrated water resources management: The seven mismatches. Int J Water Resources Dev, 20: 565-575

Rockström J, Steffen W, Noone K, Persson Å, Chapin III F S, Lambin E F, Lenton T M, Scheffer M, Folke C, Schellnhuber H J, Nykvist B, de Wit C A, Hughes T, van der Leeuw S, Rodhe H, Sörlin S, Snyder P K, Costanza R, Svedin U, Falkenmark M, Karlberg L, Corell R W, Fabry V J, Hansen J, Walker B, Liverman D, Richardson K, Crutzen P, Foley J A. 2009. A safe operating space for humanity. Nature, 461: 472-475

Song C. 2019. Preface to the special issue on the ecological-hydrological processes in the Heihe River Basin: Integrated research on observation, modeling and data analysis. J Geogr Sci, 29: 1437-1440

Steffen W, Richardson K, Rockström J, Cornell S E, Fetzer I, Bennett E M, Biggs R, Carpenter S R, de Vries W, de Wit C A, Folke C, Gerten D, Heinke J, Mace G M, Persson L M, Ramanathan V, Reyers B, Sörlin S. 2015. Planetary boundaries: Guiding human development on a changing planet. Science, 347: 1259855

Tang Q. 2020. Global change hydrology: Terrestrial water cycle and global change. Sci China Earth Sci, 63: 459-462

The World Economic Forum. 2013. The global risks 2013, Eighth Edition. Geneva, Switzerland. https://reports.weforum.org/global-risks-2013/. Accessed 11 January 2020

Tian J, Zhang B, He C, Han Z, Bogena H R, Huisman J A. 2019. Dynamic response patterns of profile soil moisture wetting events under different land covers in the mountainous area of the Heihe River Watershed, Northwest China. Agric For Meteor, 271: 225-239

Tian J, Zhang B, He C, Yang L. 2017. Variability in soil hydraulic conductivity and soil hydrological response under different land covers in the mountainous area of the Heihe River Watershed, Northwest China. Land Degrad Develop, 28: 1437-1449

United Nations (UN). 2019. The sustainable development goals report. New York. http://www.un.org/sustainabledevelopment. Accessed 11 January 2020

USACE (US Army Corps of Engineers). 2012. Water in the U.S. American West: 150 years of adaptive strategies. http://naturalresourcespolicy.org/ docs/water-in-the-west.pdf. Accessed 11 January 2020

USEPA (US Environmental Protection Agency). 1995. Watershed protection: A statewide approach. Office of Water, EPA 841-R-95-004. Washington, D. C

USEPA (US Environmental Protection Agency). 1999. Protocol for developing nutrient TMDLs. Report No EPA 841-B-99-007. Washington, DC

Vörösmarty C J, Green P, Salisbury J, Lammers R B. 2000. Global water resources: Vulnerability from climate change and population growth. Science, 289: 284-288

WWAP (United Nations World Water Assessment Programme). 2006. The United Nations World Water Development Report 2. Water: A Shared Responsibility. UNESCO, Paris

WWAP (United Nations World Water Assessment Programme). 2017. The United Nations World Water Development Report 2017. Wastewater: The Untapped Resource. UNESCO, Paris

WWAP (United Nations World Water Assessment Programme). 2019. The United Nations World Water Development Report 2019: Leaving No One Behind. UNESCO, Paris

Zacharias S, Bogena H, Samaniego L, Mauder M, Fuß R, Pütz T, Frenzel M, Schwank M, Baessler C, Butterbach-Bahl K, Bens O, Borg E, Brauer A, Dietrich P, Hajnsek I, Helle G, Kiese R, Kunstmann H, Klotz S, Munch J C, Papen H, Priesack E, Schmid H P, Steinbrecher R, Rosenbaum U, Teutsch G, Vereecken H. 2011. A network of terrestrial environmental observatories in Germany. Vadose Zone J, 10: 955973 
Zalewski M. 2000. Ecohydrology-The scientific background to use ecosystem properties as management tools toward sustainability of water resources. Ecol Eng, 16: 1-8

Zhang L, He C, Zhang M, Zhu Y. 2019. Evaluation of the SMOS and SMAP soil moisture products under different vegetation types against two sparse in situ networks over arid mountainous watersheds, North- west China. Sci China Earth Sci, 62: 703-718

Zipper S C, Jaramillo F, Wang-Erlandsson L, Cornell S E, Gleeson T, Porkka M, Häyhä T, Crépin A S, Fetzer I, Gerten D, Hoff H, Matthews N, Ricaurte-Villota C, Kummu M, Wada Y, Gordon L. 2020. Integrating the water planetary boundary with water management from local to global scales. Earth's Future, 8: e01377 